\title{
XPS スペクトルのスムージング処理
}

\author{
齋 藤健 \\ サーモフィッシャーサイエンティフィック株式会社＼cjkstart画221-0022＼cjkstart神奈川県横浜市神奈川区守屋町 3-9
}

（2015 年 10 月 19 日受付；2016年 1 月 28 日掲載決定）

\section{Smoothing of XPS Spectrum}

Takeru SAITO

Thermo Fisher Scientific K.K., 3-9 Moriya-cho, Kanagawa-ku, Yokohama, Kanagawa 221-0022

(Received October 19, 2015 ; Accepted January 28, 2016)

KEYWORDS : smoothing, moving transfer, Savitzkey-Golay, XPS

\section{1. は じめに}

$\mathrm{X}$ 線光電子分光法（XPS）は固体表面近傍（～10 nm 程度）の元素組成や化学状態の解析に広く応用されてい る。しかしながら, 微量元素の測定時などは, スペクト ル取得時の積算回数を増しても十分な信号強度を得られ ず，ノイズの影響を大きく受けてしまうことがある。ま た，試料がダメージを受けやすく，短時間の測定を余儀 なくされ，十分な信号強度が得られない場合もある。そ のような場合, 測定データのスムージング (平滑化処 理）を行い, ノイズ成分を低減後, 各種データ処理を行 うことがある ${ }^{1,2)}$ 。

近年の XPS 装置付属のソフトウエアには各種スムー ジング法が標準で搭載されるようになり, 操作は簡単に 行えるようになっている。XPS 装置の普及にともない 応用分野は広がり, 様々なレベルのユーザーが XPS 測 定を行うようになっている。そのため, 解析手法の詳細 な内容や, 結果として受ける影響を十分理解せずに使用 されることもしばしばである。解析時のパラメーター選 択の理由が “前任者と同じものを採用した”とか, “ソ フトウエアの初期值をそのまま用いた”など, 十分な吟 味がなされないまま適用されている事例も散見される。 しかしながら，選択するパラメーターの設定をあやまる と, 真実とは異なるスペクトル形状になってしまう恐れ がある。

E-mail : takeru.saito@thermofisher.com
本解説では，XPS で比較的用いられている代表的な スムージング法を紹介し，簡単な適用例を示し，その注 意点について解説する。

\section{2.スムージング}

スムージングは, XPS のスペクトルのように連続し て変化しているデータにおいて, ある点に関して周辺の データを用いて各デー夕点間の相関を高めてデータがス ムーズにつながるようにし, 相関性のない特異点やノイ ズの影響を除去するためのデー夕処理法である。

Fig. 1 に代表的なスムージング法の例として, 単純移 動平均法（A）と Savitzkey-Golay 法（B）でデー夕解析 を行った例を示す。本例では, 同一データに関して, そ れぞれの方法で 5 点スムージングを行った。SavitzkeyGolay 法ではフィッティングの多項式に 2 次関数を用い た。

\section{1 単純移動平均法 ${ }^{1,2)}$}

単純移動平均法はもっとも単純なスムージングの方法 で,ソフトウエアには “Simple”もしくは“Moving Average” と記述されていることがある。この方法は, あるエネルギー值のデータに関して, 周辺のデー夕值を 含めた単純な平均值を計算する方法である。たとえば, Fig. 1（A）のように, 着目している目的の点と前後 2 点の合計 5 点 ( $\square$ ) の平均値を計算し, その結果を新し い值（○）として採用する。計算が終了したら次の点以 降も同様の計算を繰り返し行う。一連の計算で得られた 結果を用いて, スムージングを繰り返し行うことも可能 

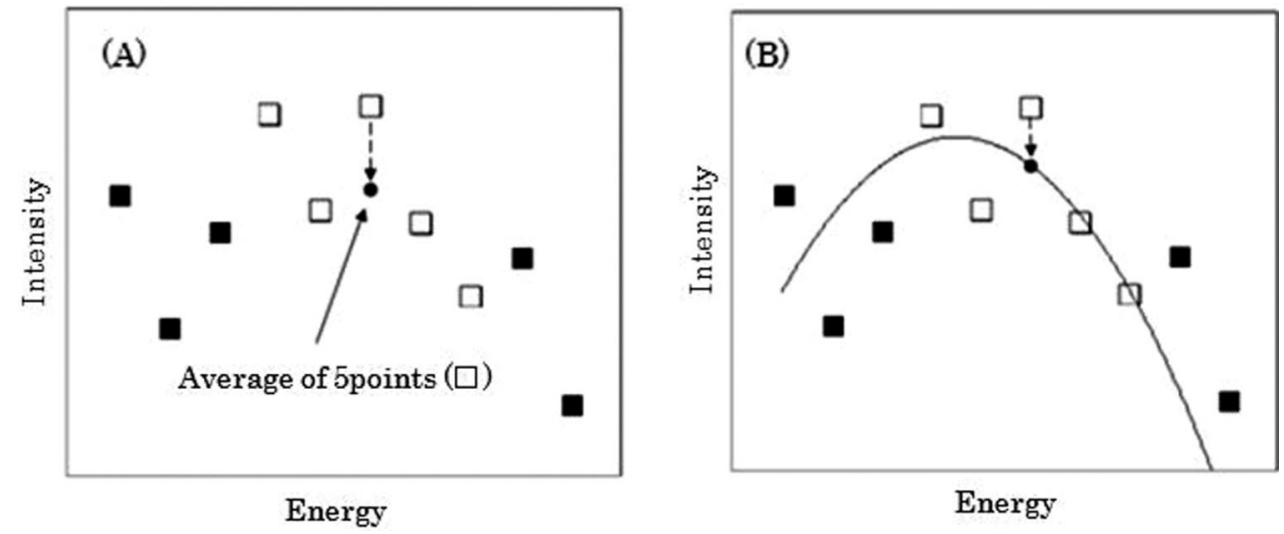

Fig. 1. Example of data smoothing by Moving Average method (A) and Savitzky-Golay Method (B).

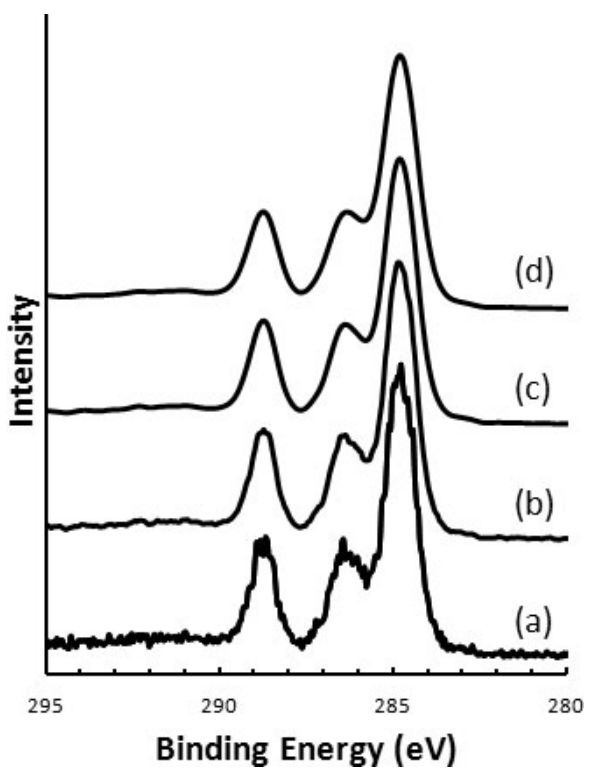

Fig. 2. C1s XPS spectra of PET Film before and after smoothing by Moving Average method. (Raw data (a) and 5 points (b), 7 points (c), 9 points (d)).

である。計算式としては, ある $\mathrm{n}$ 番目の点の単純移動平 均法によって計算された新しい值は次式のようになる。

$$
I_{n^{\prime}}=\frac{\left(I_{n-2}+I_{n-1}+I_{n}+I_{n+1}+I_{n+2}\right)}{5}
$$

Fig. 2 に PET 試料の C1s XPS スペクトルと単純移動 平均法でスムージングを行った例を示す。眓ではスムー ジング前のスペクトル (a)，スムージング時に 5 点 (b), 7 点 (c), 9 点 (d) それぞれで1 回のスムージン グ計算を行った例を示す。スペクトルは $0.05 \mathrm{eV}$ ステッ プで測定され，ピークの半值全幅（FWHM）は約 1.0 $\mathrm{eVであった。}$

スムージングの点数の増加とともにスペクトルはなめ らかになり，スムージングの効果が現れるが，その一方
でピークがブロードになり，微細な構造が失われピーク の強度も減少している。このように単純平均計算を行う と，ピークがブロードになり強度が下がる傾向があるな ど，スペクトル形状に与える影響が大きいため，本来の スペクトルを再現できないなどの問題があり，近年はあ まり使用されていない。一般的には後述する SavitzkeyGolay 法が用いられることが多い。

2.2 Savitzkey-Golay 法 (サビツキー・ゴーレー法) ${ }^{3)}$ 単純移動平均法では, 目的の点拉よび前後のデー夕を 用いて平均値を求める方法であるが, Savitzkey-Golay 法 は多項式を用いて最小二乗法でフィッティングを行う方 法である。

Fig. 1（B）の例は，スムージングの点数を 5 点， 2 次 関数を用いた場合の結果である。着目している目的の点 と前後 2 点の合計 5 点（ $\square ）$ に対して, 2 次関数により フィッティングを行う。初期の中心点の值を計算值 （○）に置き換え，同様の計算を他の点にも適用する。

Fig. 3 に PET 試料の C1s XPS スペクトルを SavitzkeyGolay 法でスムージングを行った例を示す。2 次関数を 用い 5 点スムージングの回数を変化させ，スペクトル形 状の変化を検討した。スペクトルの取得は Fig. 2 と同様 でスムージング前のスペクトル (a)，5回（b)，10回 (c)，40 回 (d) それぞれの回数スムージング計算を行 った結果を示す。スムージング回数の増加にともないノ イズが低減され，スペクトルが滑らかになっている。

Fig. 4 に Fig. 3 の場合と同様に PET 試料の C1s XPS ス ペクトルを Savitzkey-Golay 法で， 5 点，7点，9点それ ぞれでスムージングを繰り返し行った場合の C-C 結合 に帰属される $285 \mathrm{eV}$ 付近のメインピークの半值幅およ びピーク強度の変化を示す。5 点のスムージングの場合 には，スムージングを繰り返し行っても，Fig. 3 で示し たとおり半值幅とピーク強度の変化はわずかであるが, スムージング点数を増やすと変化が大きくなり, 9 点の 


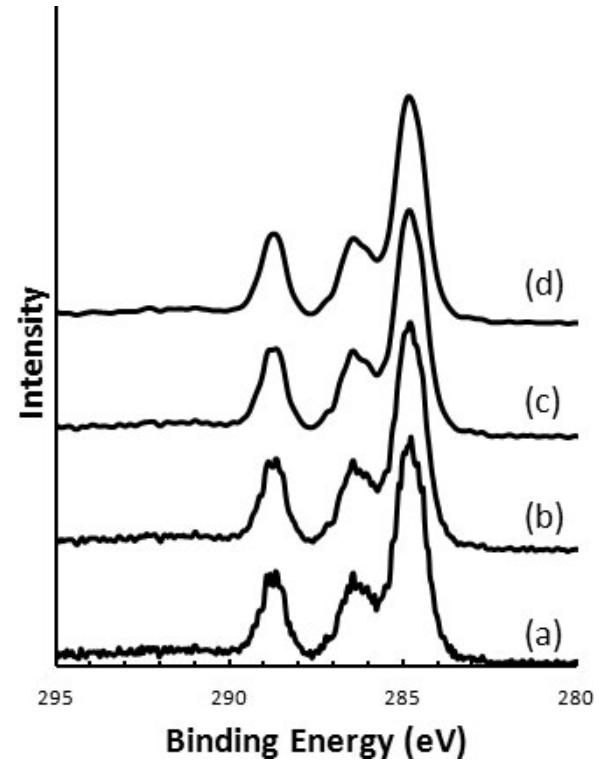

Fig. 3. C1s XPS spectrum of PET Film before and after smoothing by Savitzkey-Golay method. (5 points, Quadratic). (Raw data (a) and Smoothed 5 times (b), 10 times (c), 40 times (d)).

スムージングでは, 半值幅が増加し， $5 \%$ 以上のピーク 強度の減少が認められスペクトル形状が大きく変化して いることがわかる。

Savitzkey-Golay 法では, 多項式の次数, スムージング 点数, スムージング回数のパラメーターが存在するが, スムージング処理によって, 多少なりともスペクトル形 状は変化するので, それぞれの影響に関して十分理解 し, 以下の注意点を考慮して適切なパラメーターの選択 が必要不可欠である ${ }^{3,4)}$ 。

1）多項式の次数は大きいほど, 元のデータにフィッ トしやすくなるが，スムージングの効果は小さくなる。 一般的には 2 次もしくは 3 次が用いられる。

2）スムージングの点数が多くなると, 平滑性が高く なり，スペクトルはより滑らかになるが，ピークがブロ ードになる傾向がある。点数を決める場合は, ピークの 半值全幅 (FWHM) 内に $\mathrm{N}$ 点含まれるとすると, $0.7 \mathrm{~N}$ 倍以下とする。

3）スムージングの点数は可能な限り少なくし，スム ージングの回数を増やす（たとえば 5 点で 40 回）。

4）スペクトルの両端の端点付近（n 点のスムージン グでは $(\mathrm{n}-1) / 2$ 点）はスムージングの計算処理から除 外されるため, ピークがスペクトル測定範囲の端点に近 い場合には，スムージングを繰り返し行うと，ピークが 本来の形状からゆがんでしまうため，スペクトルの測定 範囲は十分に広い必要がある。

たとえば，XPS スペクトルのピークの半值幅が $1.0 \mathrm{eV}$

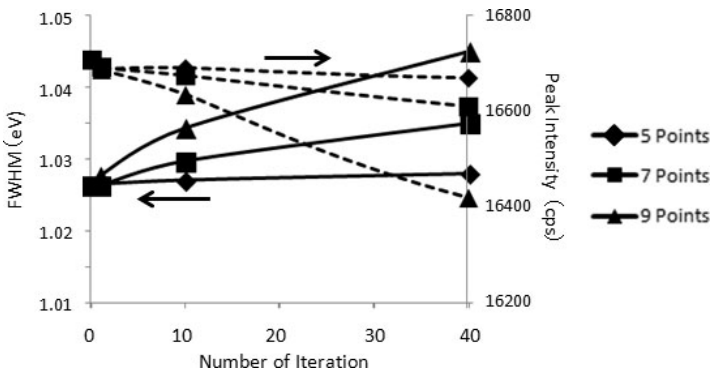

Fig. 4. Changing of FWHM and peak intensity of C1s XPS spectrum of PET Film after smoothing by Savitzkey-Golay method with changing number of iteration of smoothing. (5 points, 7 points and 9 points).

程度であり，エネルギーステップが $0.05 \mathrm{eV}$ の場合, 半 值幅の 0.7 倍の範囲に 15 点程度含まれることから, ス ムージングの点数は最大で 15 点以内である。ただし, スムージング点数を少なくしても，スムージングを繰り 返し行うとピークはブロードになり，ピークの高さが低 くなる傾向があり, 微細な構造がわかりにくくなる。そ のため，上記のように，スムージングの点数を増やすよ り, 少ない点数を選択し, 回数を増やす方が有効であ り，たとえば，5点スムージングを繰り返し行う方が良 い。スムージングを繰り返し行い, スペクトルが十分な $\mathrm{S} / \mathrm{N}$ になるところで計算を止めれば，おおよそ問題の ないスペクトルが得られるはずである。

スムージングにより，ノイズを低滅したスペクトルを 得ることが本来の目的ではあるが，スムージングによ り, もとの測定デー夕は何らかの変化が生じるので, 測 定結果の報告時には，スペクトル測定の条件等の基本情 報だけでなく，スムージング有無，用いた方法，使用し たパラメーターを明記することが望まれる。

\section{3. ま め}

PC やソフトウエアの進歩で, 複雑な解析手法も比較 的容易に利用することができるようになっているが，そ れら手法がどのような理論で行われているかを理解する ことがもっとも重要であり, デー夕や解析結果に与える 影響を十分理解し応用することが正しい結果を導き出す 上で非常に重要である。

\section{文献}

1) S. Fukushima : J. Surf. Anal. 2, 359 (1996).

2) K. Takahashi : J. Surf. Anal. 7, 68 (2000).

3) A. Savitzkey and M.J.E. Golay : Anal. Chem. 36, 1627 (1964).

4) A. Proctor and P.M.A. Sherwood : Anal. Chem. 54, 13 (1982). 